\title{
High School Agriculture Teachers' Intentions to Continue Teaching
}

\author{
Normala Ismail ${ }^{1, *}$, Greg Miller ${ }^{2}$ \\ ${ }^{1}$ Faculty of Educational Studies, University Putra Malaysia, 43400, Serdang, Selangor, Malaysia \\ ${ }^{2}$ Agricultural Education \& Studies, Iowa State University 201 Curtiss Hall, Iowa State University, Ames, IA 50011, United States
}

Received October 27, 2019; Revised December 2, 2019; Accepted December 24, 2019

Copyright $\mathrm{O} 2020$ by authors, all rights reserved. Authors agree that this article remains permanently open access under the terms of the Creative Commons Attribution License 4.0 International License

\begin{abstract}
A descriptive survey study was used to examine factors that influence high school agriculture teachers' intentions to continue teaching in Iowa. The online questionnaire was administered to 252 agriculture teachers, and 119 teachers completed the survey. A four-point Likert-type scale was used to measure agriculture teachers' intentions to continue teaching. The overall mean and standard deviation is 2.64 (.64) for the eight influential factors, which indicates that these factors slightly influenced teacher intentions to continue teaching. The multinomial logistic regression model using the stepwise forward method was used to predict the likelihood of individuals' plans to continue teaching. The model was statistically significant $\left(\chi^{2}=39.97 ; p=0.01\right)$, and the following significant, influential factors can explain 31 percent (Pseudo $\mathrm{R} 2=.31$ ) of the variance: teacher recognition $(\mathrm{p}=.001)$, teaching as a right career $(\mathrm{p}=.035)$, family expectation of staying $(\mathrm{p}=.035)$ and teaching makes oneself feel good $(\mathrm{p}=.040)$. Findings from this study support evidence from previous research that reported teachers with strong self-esteem and belief that teaching is the right career for them and will remain longer in the profession.
\end{abstract}

Keywords Agriculture Teachers, Intentions to Continue Teaching

\section{Introduction}

Teacher attrition has been acknowledged as a crucial issue in many countries, including the United States (Borman \& Dowling, 2006; Brill \& McCartney, 2008; Watt \& Richardson, 2008). Teacher attrition can be defined as the percentage of beginning teachers who leave the teaching profession (Unesco, 2017). A high number of teacher attrition will increase training costs for a new teacher and lead to difficulty in teacher retention.

Brill \& McCartney (2008) stated teacher attrition issue had been an alarming trend in the United States for a few decades (Ingersoll, 2001), where 46 percent of teachers leave within the first five years. Realizing how critical this issue is, the recruitment of new teachers is required to resolve teacher attrition problems. Although recruitment is essential, retention of teachers must be prioritized to lower teacher attrition rates (Ingersoll and Smith, 2003).

Previous studies, such as those by Camp (2000) and Edwards \& Briers (2001), focus on determining why individuals leave the teaching profession, whether they do voluntarily or involuntarily. Many of these studies were conducted more specifically on agriculture teachers to ascertain any personal problems (Myers, Dyer, \& Washburn, 2005), determine job satisfaction (Cano \& Miller, 1992; Walker, Garton, \& Kitchel, 2004) and verify there is family and work-life balance (Murray, Flowers, Croom, \& Wilson, 2011).

Until now, several teacher retention strategies have been implemented, including student loan forgiveness, scholarships, and professional development programs for early, mid-career, and late-career agriculture teachers in the US. However, these current strategies do not effectively overcome shortages of qualified agriculture teachers at school (Walker, Garton, and Kitchel, 2004). Thus, this study aims to determine factors that influence agriculture teachers' intentions to remain in teaching. This study addresses the American Association for Agricultural Education national research agenda priority related to ensuring there are enough qualified and high-quality teachers.

\section{Literature Review}

Worthy (2005) found that individuals who stay in teaching for more than five years reach their full potential 
more than those who quit. This finding is supported by previous literature, which states that teachers who have five to eight years of teaching experience often master their professions (Scherer, 2001). Individuals who stay in teaching longer gain more experience and become more effective teachers. Several studies investigating individuals' intentions to continue teaching have been carried out on beginning teachers; it has been found that many teachers leave the profession after only a few years of teaching (Wilhelm, Dewhurst-Savellis, \& Parker, 2000; Inman \& Marlow, 2004; Borman \& Dowling, 2006; Curry \& O’Brien, 2012).

\subsection{Factors Influencing Intentions to Continue Teaching}

Researchers have determined several factors that influence individuals' intentions to continue teaching. Professional knowledge and skills, teaching values, responsibilities, and preparedness, perceptions about plans to remain in teaching and self-efficacy are identified as individuals' personal and professional needs that influence their intentions to stay in teaching (Battle \& Looney, 2014; Walker, Garton, \& Kitchel, 2004; Darling-Hammond, Chung, \& Frelow, 2002; Haberman, 1989; Battle \& Wigfield, 2003). Knowledge can be defined as knowing and gaining information on something, whereas skills are about doing activities that involve practice or training (Merriam-Webster). Previous studies have reported that teachers with more relevant knowledge and skills can be expected to persist in teaching (Haberman, 1989; Darling-Hammond, 1990; Battle \& Looney, 2014).

Delnero \& Montgomery (2001) conducted a study that incorporates teachers' responsibilities along with their knowledge and skills in teaching. For instance, teaching requires individuals to have knowledge and skills in various subject matters, curriculum review, lesson plan design, providing instruction, conducting students' learning assessments, advising students, communicating with parents, and maintaining records of student learning. Besides, Roness (2011) notes that the quality of experiences at the earliest stage in teaching careers can determine an individuals' intention to stay. This statement corroborates previous research, which has found that the initial year of one's teaching experience is essential for professional development, career satisfaction, and longevity (McCormack, Gore, \& Thomas, 2006).

Preparedness and self-efficacy have also been identified as influential factors for individuals to continue teaching (Darling-Hammond, Chung, \& Frelow 2002). Teachers with sufficient preparation can produce more effective lessons that will benefit students as well as satisfy themselves as teachers. Bandura (1977) claims that positive relationships between new teachers and their students enhance students' quests for learning, which contributes positively to teachers' feelings of fulfillment.
Adding to this, Monk (1994) has found a positive correlation between teachers' subject matter preparedness and student achievement.

Battle \& Looney (2014) studied individuals' intentions to remain in teaching by investigating teachers' values and perceptions of education and concluding that there is a positive relationship between intrinsic-attainment and utility value; moreover, Battle \& Looney reported that there is a negative relationship between cost and intentions to continue teaching. Roness (2011) found that feelings of happiness and positive perceptions retain teachers longer. Furthermore, it has also been found that new teachers perceive difficulty in teaching, task assignments, and work conditions as important factors influencing them to stay (Hope, 1999). Kutcy \& Schulz (2006) and Huberman (1989) described the first year or two of teaching as "a time of survival," while Skaalvik \& Skaalvik (2008)wrote that negative perceptions of teaching can cause new teachers to quit early. Finally, the mismatch between teachers' expectations and the reality of teaching might also make teachers leave the profession early (Chambers, Coles, \& Roper, 2002).

\subsection{Plans to Remain in Teaching}

Previous studies show that individuals' plans to remain in teaching are associated with their intentions and commitment to teaching (Delnero \& Montgomery, 2001). Rots, Aelterman, Vlerick, \& Vermeulen (2007) linked commitment to individuals' intentions to teach. They also underlined the significance of teacher commitment to addressing teacher attrition problems. Data from previous findings of beginning teachers' plans to stay consistently show that many teachers planned to quit teaching after only five years of service (Ingersoll \& Smith, 2003; Hughes, 2012; Whittington, McConnell, \& Knobloch, 2006). The results from the studies indicate that experienced teachers are more likely to continue teaching until retirement age.

Studies regarding agriculture teacher intent to remain in the teaching profession found four critical factors that influence commitment to stay, including agriculture work experience, responsibility to teach agriculture, self-efficacy and human capital investment in teaching agriculture (Edwards \& Briers, 2001; Whittington, McConnell, \& Knobloch, 2006). Agriculture teachers in Iowa State might have different intentions to continue teaching, but far too little attention has been paid to this type of study. Therefore, this research was conducted to understand the factors that influence high school agriculture teachers' intentions to continue to teach in Iowa.

\subsection{Conceptual Framework}

The conceptual framework for this study was derived from the expectancy-value theory. Expectancy-value theory emphasizes that individual choice, persistence, and 
performance explain how well individuals believe, perform, and value activities (Wigfield \& Eccles, 2000). Several studies have used expectancy-value theory as a framework to the issues of career choice, which suggest that individual values and expectations are essential determinants in choosing a career.

Investigate the prediction of outcomes. In different, this theory was adopted to examine career processes work results in addition to selecting jobs (Feather, 1992). The expectancy-value theory was used as a framework to study the predictors of future employment status (Lynd-Stevenson, 1999). Besides, Borders, Earleywine, \& Huey (2004) predicted the problematic behaviors of high school students by using expectancy-value theory. Eccles (1987) also extended expectancy-value theory to study the issues of career choice, which suggest that individual values and expectations are important determinants in choosing a career.

The concept of task value in the expectancy-value theory is appropriate to predict individuals' intentions (Battle \&
Wigfield, 2003; Eccles, 1983). The task value constructs, in theory, consist of utility, importance, and interest items, which collectively affect an individual's achievement outcomes. A previous study used the task value portion to predict individuals' intentions to continue teaching (Battle \& Looney, 2014). Parsons, Adler, \& Meece (1984), in their study of students' educational plans, found that task value emerged as a significant predictor.

An adaption of the subjective task value concept in the expectancy-value theory was used as a guide to frame the present research study conceptually. In this research, the conceptual framework consists of demographic variables, a curriculum for agricultural science education (CASE), and non-CASE factors that influence individuals' intentions to continue teaching, as seen in Figure 1. These factors include teachers' knowledge and skills, perception of plans to remain in teaching, early teaching experiences, teaching responsibilities, and teaching values. The selection of these factors was based on studies by Battle \& Looney (2014) and Battle \& Wigfield (2003).

Independent Variables

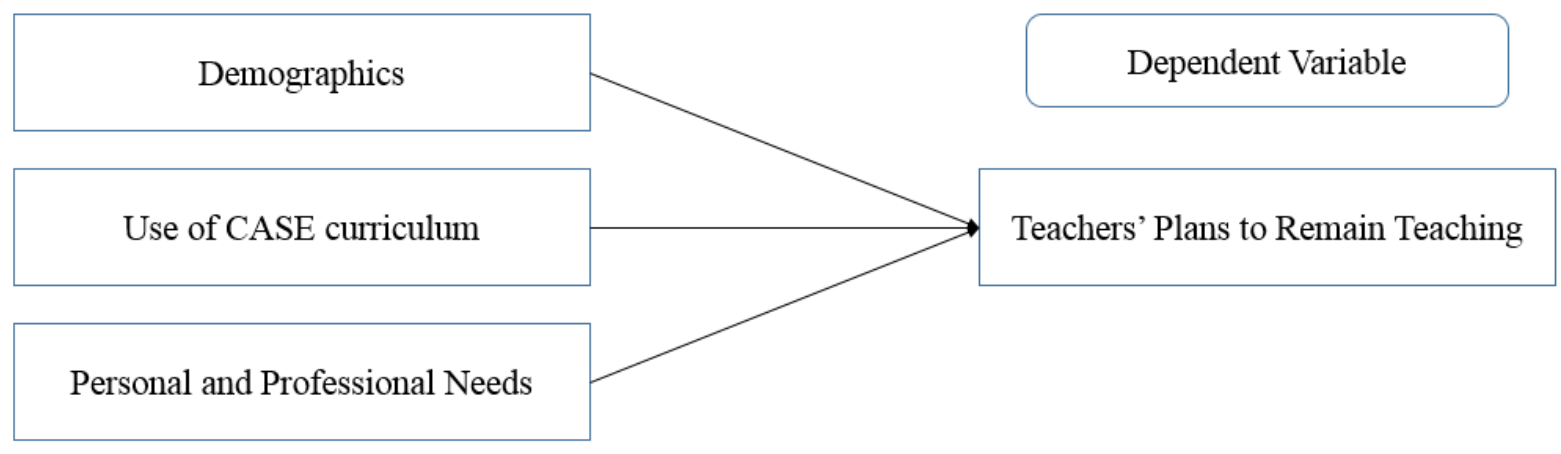

Figure 1. Conceptual framework of factors that influence high school agriculture teachers' intentions to continue teaching 


\subsection{Purpose and Objectives}

The purpose of the study was to investigate factors that influence high school agriculture teachers' intentions to continue teaching. Objectives of the study include:

1. Describe the personal characteristics of agriculture teachers in terms of age, gender, educational levels, years of teaching experience, years of teaching agriculture courses, use of the CASE curriculum, and individuals' plans to remain in teaching.

2. Describe the factors that influence individuals' intentions to continue teaching.

3. Predict individuals' plans to remain teaching from the factors that influence their intentions to continue teaching.

\section{Methodology}

The purpose of this descriptive survey study was to investigate the personal and professional needs that influence high school agriculture teachers' intentions to continue teaching. This was a census study that focused on 252 high school agriculture teachers in Iowa State. The list of participants was obtained from the Iowa State Future Farmers of America Organization.

\subsection{Instrument}

A questionnaire was developed using the Qualtrics online survey-making software consisted of four parts; however, only parts two and four are used in the manuscript. Part two of the online questionnaire has been adapted from the work of previous scholars (Kyriacou \& Kunc, 2007; Battle \& Looney, 2014). It contains Likert-type and multiple-choice items. There are eight Likert-type items measuring factors that influence individuals' intentions to teach. Response options range between $1=$ strongly disagree, $2=$ disagree, $3=$ agree, and $4=$ strongly agree. Three multiple-choice questions were used to measure knowledge and skills, early teaching experience and aspirations to move into administration, respectively. Part four contains several demographic items, and one item focused on individuals' plans to remain in teaching.

\subsection{Validity}

A panel of three agricultural education experts was appointed to review the validity of the questionnaire. One expert was satisfied with the instrument face, content, and construct validity, while the other two experts recommended a few changes. The researcher made the changes as recommended by the experts and resent the questionnaire to the panel. All three of the experts agreed that the questionnaire's face, content, and the construct were valid.

\subsection{Reliability}

A pilot study was conducted before formal data collection. The pilot study involved ten high school agriculture teachers in Iowa State. Internal consistency of needs that influence high school agriculture teachers' intentions to continue teaching was computed using Cronbach's alpha. The reliability coefficient was 0.75 .

\subsection{Data Collection}

In formal data collection, the researcher followed the tailored design method (Dillman, Smyth, \& Christian, 2009). The pre-notification email was sent to 252 agriculture teachers in Iowa State. Three days later, the researcher sent a second email via Qualtrics that included information about the study and a URL link to the questionnaire. Ten days then, a reminder was sent via Qualtrics to the non-respondents.

After an additional week, a second reminder email was sent to respondents via Qualtrics to ask for help from the non-respondent teachers. A postcard that included the URL link to the survey was sent through the U.S. Postal Service to the non-responding teachers as a last contact seven days after the second reminder. The researcher used a postcard as a different mode to contact the non-respondents to increase the response rate (Dillman, Smyth, \& Christian, 2009). The final response rate for all five methods of contact was 47 percent $(n=119)$. One week after the last communication, the online questionnaire was closed.

\subsection{Data Analysis}

Participant answers from the online questionnaires were gathered from Qualtrics, and the data were processed and analyzed using the Statistical Packages for Social Science (SPSS) version 23.0. After the formal study data collection, the Cronbach alpha value was used again to measure reliability on factors that influence agriculture teachers' intentions to continue teaching. The reliability coefficient was 0.73 .

The researcher compared early responses $(n=60$, the first half participants) to late responses $(n=59$, the second half participants) using an independent sample t-test. Results show that there was no significant difference between early and late respondents. It provides some evidence of representation for the entire population of agriculture teachers in Iowa (Lindner, Murphy \& Briers, 2001).

This was a census study; therefore, the researcher acknowledges some questions could be raised about whether inferential statistics were appropriate. Only 119 agriculture teachers completed the questionnaire, which served as a valid sample from a population of 252 total teachers contacted to participate. In agricultural education, it is customary to use inferential statistics in similar situations. It is recommended readers interpret the findings 
given this context. For example, in the regression model, we recommend placing more emphasis on coefficients and less on p-value and standard error.

Descriptive statistics, including frequencies, means, and standard deviations, were used for the first and second objectives. Research objective three was tested using the chi-square test for association. Multinomial stepwise logistic regression was used to predict teachers' plans to remain in teaching from the personal and professional needs that influence the intention to continue teaching. The level of significance was 0.05 for the entire statistical test.

\section{Analysis and Findings}

\subsection{Descriptive Analysis}

\section{Objective 1:}

Describe the personal characteristics of agriculture teachers in terms of age, gender, educational levels, years of teaching experience, years of teaching agriculture courses, use of CASE curriculum, and teachers' plans to remain in teaching.

The participants in the study consisted of 119 high school agriculture teachers from Iowa State. Of the 199 teachers, 52.9 percent identified as female, and 47.1 percent identified as male. The teachers ranged in age from 21 to 65 years. The average age was 38.15 with a standard deviation of 13.12. The teachers were asked to indicate their highest level of academic attainment. For a majority of teachers (63 percent), a bachelor's degree was their highest level of educational achievement; for the remaining 37 percent of teachers, the highest level of education was a master's degree. Years of teaching experience ranged from 1 to 40 years with an average of 14.11 and a standard deviation of 12.49. Teachers were also asked to indicate the number of years they taught agricultural education explicitly. Results show that years of teaching agriculture courses ranged from 0 to 40 years with a mean of 13.80 and a standard deviation of 12.52 .

Table 1. Age, Years of Teaching and Years of Teaching Agriculture Courses $(n=119)$

\begin{tabular}{|c|c|c|c|c|}
\hline Variable & Min & Max & $M$ & $S D$ \\
\hline Age & 21 & 65 & 38.15 & 13.12 \\
\hline $\begin{array}{c}\text { Years of Teaching } \\
\text { Experience }\end{array}$ & 1 & 40 & 14.11 & 12.49 \\
\hline $\begin{array}{c}\text { Years of Teaching } \\
\text { Agriculture Courses }\end{array}$ & 0 & 40 & 13.80 & 12.52 \\
\hline
\end{tabular}

Table 1 shows additional information regarding teachers' characteristics. The number of teachers who use the CASE curriculum was 85 (71.4 percent). A majority ( $\mathrm{f}=71,59.7$ percent) of the respondents taught "Introduction to Agriculture, Food, and Natural Resources." This was followed by the teachers who taught CASE "Principles of Agriculture Science Animal" ( $\mathrm{f}=42,35.3$ percent) and teachers who taught CASE "Principles of Agricultural Science Plant" ( $f=30,31.9$ percent). Almost 20 percent (f $=22,18.5$ percent) of the respondents taught CASE "Natural Resources and Ecology," and a small number of teachers ( $\mathrm{f}=7,5.9$ percent) taught CASE "Animal and Plant Biotechnology." Nine teachers (7.6 percent) taught CASE "Food Science and Safety" and "Agricultural Power and Technology." Seven (1.7 percent) taught CASE "Agricultural Research and Development" courses.

Many teachers noted that they plan to be in teaching for 11 or more years ( $f=54,45.4$ percent), whereas 35.3 percent $(f=42)$ of agriculture teachers plan to teach for one to five years. A small number of agriculture teachers plan to remain in teaching for six to ten years $(\mathrm{f}=21,17.6$ percent).

Table 2. Selected Personel Characteristics of High School Agriculture Teachers ( $\mathrm{n}=119)$

\begin{tabular}{|c|c|c|}
\hline Variables & $f$ & $\%$ \\
\hline Yes & & \\
No & 85 & 71.4 \\
\hline Number of Agriculture Teachers using CASE Courses & 34 & 28.6 \\
\hline Introduction to Agriculture, Food and Natural Resources & 71 & 59.7 \\
Principles of Agriculture Science Animal & 42 & 35.3 \\
Principles of Agriculture Science Plant & 38 & 31.9 \\
Natural Resources and Ecology & 22 & 18.5 \\
Food Science and Safety & 9 & 7.6 \\
Animal and Plant Biotechnology & 7 & 5.9 \\
Agricultural Power and Technology & 7 & 5.9 \\
Agricultural Research and Development & 2 & 1.7 \\
Mechanical System in Agriculture & 0 & 0.0 \\
Environmental Science Issues & 0 & 0.0 \\
Agriculture Business and Foundations & 0 & 0.0 \\
Agricultural Marketing and Communications & 0 & 0.0 \\
\hline Teachers' Plans to Remain Teaching & & \\
1-5 Years & 42 & 35.3 \\
6-10 Years & 21 & 17.6 \\
11 or more Years & 54 & 45.4 \\
\hline
\end{tabular}




\section{Objective 2:}

Describe factors that influence teachers' intentions to continue teaching.

The teachers responded to eight statements representing personal and professional needs that influence individuals' intentions to continue teaching. A Likert-type scale with four-points ranging from strongly disagree (1) to strongly agree (4) was used. A decision rule was created to interpret scores, as shown in Table 3.

Table 3. Decision Rule to Interpret the Mean Scores for the Likert Type Scale

\begin{tabular}{|c|c|c|}
\hline Likert -type categories & Mean Score & Interpretation of the statement \\
\hline 1 & $1.00-1.5$ & Strongly Disagree (Negative) \\
\hline 2 & $1.51-2.5$ & Disagree (Negative) \\
\hline 3 & $2.51-3.5$ & Agree (Positive) \\
\hline 4 & $3.51-4.0$ & Strongly Agree (Positive) \\
\hline
\end{tabular}

Table 4 shows the means and standard deviations of factors that influence their intentions to stay in the teaching profession. The grand mean for the needs was 2.64, with a standard deviation of 0.64 . This finding suggests that, overall, it slightly influenced individuals' intentions to teach. Regarding influential factors, agriculture teachers provided the highest mean score for the item "I want to stay because I believed that I could positively affect student performance" at $3.29(\mathrm{SD}=.56)$. This was followed by "I want to stay because teaching is the right career for me" with a mean of 2.99 and a standard deviation of 0.66. Agriculture teachers rated the item "I will end up getting a promotion if I stay in teaching" $(\mathrm{M}=1.97, \mathrm{SD}=.62)$ as the lowest factor that influenced their intentions to teach.

Most teachers ( $\mathrm{f}=73,61.3$ percent) indicated that knowledge of subjects and skills in teaching were relevant influencers to continue teaching, as shown in Table 5. Most of the teachers ( $\mathrm{f}=103,86.6$ percent) indicated that they had a negative experience early in their career, and even more ( $\mathrm{f}=105,88.2$ percent) identified that they had no aspirations of moving into administration.

Table 4. Factors that Influence High School Agriculture Teachers' Intention to Continue Teaching ( $\mathrm{n}=119)$

\begin{tabular}{|c|c|c|c|}
\hline Questions & $\mathrm{M}$ & $\mathrm{SD}$ & Interpretation \\
\hline $\begin{array}{c}\text { Teaching will help me fulfill future personal } \\
\text { objectives. }\end{array}$ & 2.66 & 0.69 & Positive \\
\hline $\begin{array}{c}\text { I choose to stay in teaching because I need to be } \\
\text { recognized as a teacher. }\end{array}$ & 2.34 & 0.72 & Negative \\
\hline My family expects me to stay in teaching. & 2.16 & 0.69 & Negative \\
\hline I will end up getting a promotion if I stay in teaching. & 1.97 & 0.62 & Positive \\
\hline Total & 2.64 & 0.64 & \\
\hline
\end{tabular}

Note: Based on scale: 1 = Strongly Disagree, 2 = Disagree, 3 = Agree, 4 = Strongly Agree.

Table 5. Teachers' Perception of Knowledge and Skills, Early Teaching Experience and aspiration Relative to School Management ( $\mathrm{n}=119)$

\begin{tabular}{|c|c|c|}
\hline Variables & $\mathrm{f}$ & $\%$ \\
\hline Perceptions of Importance: & & \\
Knowledge of the subject is most important & 5 & 4.2 \\
Skills in teaching are most important & 41 & 34.5 \\
Both are equally important & 73 & 61.3 \\
\hline Had negative experience in the first years of teaching & & \\
Yes & 103 & 86.6 \\
No & 16 & 13.4 \\
\hline Have aspirations of moving into administration & 14 & 11.8 \\
Yes & 105 & 88.2 \\
\hline
\end{tabular}

\subsection{Multinomial Logistic Regression Analysis}

Objective 3:

Predict teachers' plans to remain teaching from factors that influence their intentions to continue teaching. 
Multinomial logistic regression was used to predict three different plans to stay in teaching from the needs that influence individuals' intentions to continue teaching. Predictor variables that were considered and retained after the multinomial logistic regression analysis are listed in Table 6 . The dependent variable plans to stay in teaching and is broken down into three groups: 1-5 years, $6-10$ years and 11 or more years. The baseline category was planning to stay for 1-5 years. Multinomial logistic regression using the forward entry stepwise method was used to reduce eight predictor variables to four. The assumption was met; the correlational matrix for predictor variables shows no multicollinearity issues.

Table 6. Variables Considered and Retained for Predicting Teachers' Plans to Stay in Teaching

\begin{tabular}{|c|c|}
\hline Variables & $\begin{array}{l}\text { Variables retained in the final model by } \\
\text { stepwise logistic regression. }\end{array}$ \\
\hline \multicolumn{2}{|l|}{$\begin{array}{l}\text { Factors that Influence Agriculture Teachers' } \\
\text { Intentions to Continue Teaching: }\end{array}$} \\
\hline \multicolumn{2}{|l|}{$\begin{array}{l}\text { 1. Stay because I believe that I have the ability } \\
\text { to positively affect student performance. }\end{array}$} \\
\hline 2. Stay because teaching is the right career. & $\begin{array}{l}\text { 2. Stay because teaching is the right } \\
\text { career. }\end{array}$ \\
\hline \multicolumn{2}{|l|}{ 3. Teaching fulfills my needs. } \\
\hline $\begin{array}{l}\text { 4. Staying in teaching because it makes me feel } \\
\text { good about myself in the future. }\end{array}$ & $\begin{array}{l}\text { 4. Staying in teaching because it makes } \\
\text { me feel good about myself in the future. }\end{array}$ \\
\hline \multicolumn{2}{|l|}{$\begin{array}{l}\text { 5. Teaching will help me fulfill future personal } \\
\text { objectives. }\end{array}$} \\
\hline $\begin{array}{l}\text { 6. Staying in teaching is to be recognized as a } \\
\text { teacher. }\end{array}$ & $\begin{array}{l}\text { 6. Staying in teaching is to be recognized } \\
\text { as a teacher. }\end{array}$ \\
\hline 7. The family expects me to stay in teaching. & $\begin{array}{l}\text { 7. The family expects me to stay in } \\
\text { teaching. }\end{array}$ \\
\hline $\begin{array}{l}\text { 8. I will end up getting a promotion if I stay in } \\
\text { teaching. }\end{array}$ & \\
\hline
\end{tabular}

Table 7. Multinomial Logistic Regression (Model included significant variables at .05 level of significance)

\begin{tabular}{|c|c|c|c|c|c|c|c|}
\hline Variable & & Estimate & SE & Wald & df & $\mathrm{P}$ & Odd Ratio \\
\hline \multicolumn{8}{|c|}{ Plans to Continue Teaching } \\
\hline \multirow[b]{2}{*}{6 to 10 Years } & Intercept & 1.31 & 1.98 & 0.438 & 1 & 0.51 & \\
\hline & $\begin{array}{c}\text { Staying in teaching to be recognizd } \\
\text { as a teacher }\end{array}$ & -1.32 & 0.56 & 5.60 & 1 & 0.02 & 0.27 \\
\hline \multirow{5}{*}{$\begin{array}{l}11 \text { or more } \\
\text { Years }\end{array}$} & Intercept & -4.12 & 1.84 & 5.03 & 1 & 0.03 & \\
\hline & Staying in teaching makes me feel good about oneself in the future. & 1.03 & 0.50 & 4.19 & 1 & 0.04 & 2.80 \\
\hline & Staying in teaching to be recognized as a teacher & -1.51 & 0.46 & 11.02 & 1 & 0.01 & 0.22 \\
\hline & Staying because teaching is a right career & 1.09 & 0.52 & 4.47 & 1 & 0.04 & 2.99 \\
\hline & Family expects to stay in teaching & -0.80 & 0.38 & 4.44 & 1 & 0.04 & 0.45 \\
\hline
\end{tabular}

Note: $(n=119)$. The reference category is 1 - 5 years. Model fit $\left(\chi^{2}=39.97 ; p=0.01\right)$.

Based on Table 7, results show that the model was statistically significant $\left(\chi^{2}=39.97 ; \mathrm{p}=0.01\right)$, where Pseudo R2 (Nagelkerke) was 0.31, as shown in Table 7. The odds ratio was used to interpret the multinomial logistic regression analysis for individuals' plans to stay in teaching for 6-10 years relative to the 1-5 year plan. Results indicate that agriculture teachers who have a one-unit increase in their scale score with the variable "stay in teaching to be recognized as a teacher," the odds of a teacher being likely to stay for 6-10 years decreases by a factor of 0.27 while other variables are held constant. The odds ratio depicted teachers with this variable as likely preferring short-term plans (remaining in teaching for 1-5 years) as opposed to long-term projects (remaining in teaching for 11 or more years).

Besides, the odds ratio was used to interpret the multinomial logistic regression analysis for teachers' plans to stay 11 or more years relative to 1-5 years. Agriculture teachers who have a one-unit increase in their scale with the variable "staying in teaching because it makes me feel good about myself in the future," the odds of the teachers planning to stay for more 11 years increases by a factor of 2.80 while other variables are held constant.

Results show that agriculture teachers who have a one-unit increase in their scale score with the variable "stay in teaching to be recognized as a teacher," the odds of the teachers who were likely to stay in 11 or more years decreases by a factor of 0.22 while other variables are held constant. This odds ratio indicated teachers were more likely to stay for $1-5$ years. Agriculture teachers who have a one-unit increase in their scale score with the variable "stay because teaching is the right career," the odds of teachers 
being likely to stay in 11 more years increases by a factor of 2.99 while other variables are held constant. Adding to this, teachers who have a one-unit increase in their scale score with the variable "family expects me to stay in teaching," the odds of the teachers planning to stay in 11 or more years decreases by a factor 0.45 while other variables are held constant.

While, Table 8 shows a classification table, and indicates how accurately the model predicts the category of three different plans to stay in teaching. The model correctly classifies 59.7 percent of agriculture teachers. The overall correct classification rate shows a 16.4 percent improvement over selecting the model category, and a 34.1 percent improvement if the dependent variable holds constant. It would be more accurate to predict agriculture teachers' plans in the 11 or more years category. Around 74.1 percent of teachers who were observed in 11 or more years plan category were predicted to be in this category.

Table 8. Classification of the Model

\begin{tabular}{|c|c|c|c|c|}
\hline Observed & \multicolumn{4}{|c|}{ Predicted } \\
\hline & $\begin{array}{c}1-5 \\
\text { Years }\end{array}$ & $6-10$ Years & $\begin{array}{c}11 \text { or more } \\
\text { Years }\end{array}$ & $\begin{array}{c}\text { Percent } \\
\text { Correct }\end{array}$ \\
\hline $1-5$ Years & 29 & 2 & 13 & 65.9 \\
\hline $6-10$ Years & 9 & 2 & 10 & 9.5 \\
\hline $\begin{array}{c}11 \text { or more } \\
\text { Years }\end{array}$ & 13 & 1 & 40 & 74.1 \\
\hline Overall \% & 42.9 & 4.2 & 58.0 & 59.7 \\
\hline
\end{tabular}

The results also show the model was best at classifying teachers who plan to stay in teaching for 11 or more years (74.1 percent) and 1-5 years (65.9 percent). However, the model poorly classifies teachers in the 6-10 years category, indicating that other predictors may better organize teachers in this category.

\section{Conclusion, Implications, and Recommendations}

The purpose of the study was to investigate the personal and professional needs that influence high school teachers' intentions to continue teaching in Iowa. The findings of this study show that many individuals plan to teach for 11 or more years. This positive finding corroborates a previous study conducted by Hughes (2012), which found that 83.5 percent of individuals plan to teach until they retire. In contrast, this finding disagrees with studies by Guarino (1996) and Johnson \& Birkeland (2003), which found that individuals do not plan to teach for their entire careers and that they view teaching as a short-term career. In this study, several teachers $(f=42,35.3$ percent $)$ planned to teach for a short period (1-5 years). This is a significant number of teachers, and their loss will contribute to the teacher shortage.

More than three quarters $(\mathrm{n}=85,71.4$ percent $)$ of respondent agriculture teachers used the CASE curriculum to teach, and the majority show "Introduction to Agriculture, Food, and Natural Resources" (AFNR). The increasing trend of agriculture teachers in Iowa becoming CASE curriculum certified and using CASE to teach will benefit both teachers and students in the classroom. The National Association of Agricultural Educators Communities of Practice (2011) reported growth and expansion of the CASE program in 17 states that implemented foundational CASE courses for plant and animal science. All Iowa programs with CASE certification increased by 30 percent from 2011 to 2013.

Influential factors show that individuals are more likely to be influenced to continue teaching because they believe they can positively affect student performance. This finding is consistent with a previous study reporting that teachers appreciate student achievement and have positive relationships with students (Taylor, McNaney-Funk, Jardine, Lehman, \& Fok-Chan, 2014). Agriculture teachers intend to stay most likely because they see the value in teaching, they want to serve students and the community well, and they want to contribute to student knowledge positively.

Professional knowledge and skills are so valuable to teachers that they noted these qualities as essential influencers for their intentions to remain in teaching. This is an agreement with previous studies that found individuals with relevant knowledge and skills intending to stay in teaching (Haberman, 1989; Darling-Hammond, 1990; Battle \& Looney, 2014; Delnero \& Montgomery, 2001). It is somewhat surprising that almost all teachers indicated they had negative early teaching experience. However, this finding supports Kutcy \& Schulz (2006) and Haberman (1989) that describe the first two years of teaching as survival time. It is recommended that school administrators and educators provide full support to novice teachers and make them feel appreciated. Additionally, partnerships between teacher educators and high school teachers can provide teachers with the survival skills necessary to remain in teaching longer.

The last objective sought to determine the contributions of factors that influence teachers' intentions to continue teaching teachers' plans to remain in teaching. The influential factors that were significant predictors of individuals' plans to continue teaching included teacher recognition, teaching as the right career, family expectation to stay, and teaching that makes oneself feel good.

Individuals who agree that teaching makes oneself feel good and that teaching is the right career are more likely to stay in education long enough to retire. This study reaffirms previous research regarding teachers' self-esteem, good feelings and acting consistently with their beliefs when teaching (Nias, 1996). Peske, Liu, Johnson, Kauffman, \& Kardos (2001) found that teachers who decided to teach were the right career for them that 
would first consider the support and compensation being giving to them by their jobs. In contrast, teachers motivated by teacher recognition and family expectation to stay are more likely to report their intentions to leave the profession within 1-5 years.

The findings from this study show that teachers have varying intentions to stay in the field of education. Policymakers should create opportunities or pathways geared toward assisting the work of both individuals that plan to teach long-term and those that plan to teach short-term. This effort would benefit agriculture teachers specifically by providing supports and heightening individual commitment to teach.

\section{Recommendations for Future Research}

The study should be replicated with agriculture teachers in other states. Future studies should determine school administrators' perceptions of individuals' intentions to stay in teaching. Also, future studies could employ qualitative methods to gain a deeper understanding of teachers' personal and professional needs and their plans to continue teaching long-term.

\section{Acknowledgments}

Research funds from Universiti Putra Malaysia supported the publication of this study. We would also like to acknowledge the contributions of the research assistants who have aided the research team in putting this together.

\section{REFERENCES}

[1] Bandura, A. (1977). Self-efficacy: Toward a unifying theory of behavioral change. Psychological Review, 84(2), 191.

[2] Battle, A., \& Looney, L. (2014). Teachers' intentions to stay in teaching: The role of value and knowledge of adolescent development. Education, 134(3), 369-379.

[3] Battle, A., \& Wigfield, A. (2003). College women's value orientations toward family, career, and graduate school. Journal of Vocational Behavior, 62(1), 56-75.

[4] Borders, A., Earleywine, M., \& Huey, S. J. (2004). Predicting problem behaviors with multiple expectancies: Expanding expectancy-value theory. Adolescence, 39(155), 539.

[5] Borman, G. D., \& Dowling, N. M. (2006). Longitudinal achievement effects of multiyear summer school: Evidence from the Teach Baltimore randomized field trial. Educational Evaluation and Policy Analysis, 28(1), 25-48.
[6] Brill, S., \& McCartney, A. (2008). Stopping the revolving door: Increasing teacher retention. Politics \& Policy, 36(5), 750-774.

[7] Camp, W. G. (2000). A national study of the supply and demand for teachers of agricultural education in 1996-1998. Blacksburg, VA: Virginia Tech. Agricultural Education Program.

[8] Cano, J., \& Miller, G. (1992). A gender analysis of job satisfaction, job satisfier factors, and job dissatisfier factors of agricultural education teachers. Journal of Agricultural Education, 33(3), 40-46.

[9] Chambers, G. N., Coles, J., \& Roper, T. (2002). Seeing it from both sides: Reasons for withdrawing from a one-year secondary postgraduate certificate in education courses. Teacher Development, 6(3), 373-390.

[10] Curriculum for Agricultural Science Education. (2016).Retrieved from http://www.case4learning.org/

[11] Curry, J. R., \& O'Brien, E. R. (2012). Shifting to a wellness paradigm in teacher education: A promising practice for fostering teacher stress reduction, burnout resilience, and promoting retention. Ethical Human Psychology and Psychiatry, 14(3), 178.

[12] Darling-Hammond, L. (1990). Instructional Policy Into Practice: "The Power of the Bottom Over the Top." Educational Evaluation and Policy Analysis, 12(3), 339347.

[13] Darling-Hammond, L., Chung, R., \& Frelow, F. (2002). Variation in teacher preparation: How well do different pathways prepare teachers to teach? Journal of Teacher Education, 53(4), 286-302.

[14] Delnero, J., \& Montgomery, D. (2001). Perceptions of work among California agriculture teachers. Journal of Agricultural Education 42(2), 56-67.

[15] Dillman, D. A., Smyth, J. D., \& Christian, L. M. (2009). Internet, mail, and mixed-method surveys: The tailored design method. Hoboken.

[16] Eccles, J. (1983). Expectancies, values and academic behaviors. Achievement and achievement motives. San Francisco: Freeman.

[17] Eccles, J. S. (1987). Gender roles and women's achievement-related decisions. Psychology of Women Quarterly, 11(2), 135-172.

[18] Education National Research Agenda: 2016-2020. Gainesville, FL: Department of Agricultural Education and Communication.

[19] Edwards, M. C., \& Briers, G. E. (2001). Selected variables related to expected longevity in the teaching of entry-phase agriculture teachers. Journal of Career and Technical Education, 18(1), 7-18

[20] Feather, N. T. (1992). Expectancy - value theory and unemployment effects. Journal of Occupational and Organizational Psychology, 65(4), 315-330.

[21] Guarino, T. (1996). Postmodernity and Five Fundamental Theological Issues. Theological Studies, 57(4), 654-689.

[22] Haberman, M. (1989). More minority teachers. Phi Delta 
Kappa, 70(10), 771-76.

[23] Hope, W. C. (1999). Principals' orientation and induction activities as factors in teacher retention. The Clearing House, 73(1), 54-56.

[24] Huberman, M. (1989). The professional life cycle of teachers. Teachers College Record.

[25] Hughes, G. D. (2012). Teacher retention: Teacher characteristics, school characteristics, organizational characteristics, and teacher efficacy. The Journal of Educational Research, 105(4), 245-255.

[26] Ingersoll, R. M. (2001). Teacher turnover and teacher shortages: An organizational analysis. American Educational Research Journal, 38(3), 499-534.

[27] Ingersoll, R. M., \& Smith, T. M. (2003). The wrong solution to the teacher shortage. Educational Leadership, 60(8), 30-33.

[28] Inman, D., \& Marlow, L. (2004). Teacher retention: Why do beginning teachers remain in the profession? Education, 124(4), 605-615.

[29] Johnson, S. M., \& Birkeland, S. E. (2003). Pursuing a "Sense of Success": New Teachers Explain Their Career Decisions. American Educational Research Journal, 40(3), 581-617.

[30] Kardos, S. M., Johnson, S. M., Peske, H. G., Kauffman, D., \& Liu, E. (2001). Counting on Colleagues: New Teachers Encounter the Professional Cultures of Their Schools. Educational Administration Quarterly, 37(2), 250-290.

[31] Knobloch, N. A. (2001). The influence of peer teaching and early field experience on teaching efficacy beliefs of preservice educators in agriculture. Proceedings of the 28th National Agricultural Education Research Conference, 119-131.

[32] Kutcy, C. E. B., \& Schulz, R. (2006). Why are beginning teachers frustrated with the teaching profession? McGill Journal of Education, 41(1), 77.

[33] Kyriacou, C., \& Kunc, R. (2007). Beginning teachers' expectations of teaching. Teaching and Teacher Education, 23(8), 1246-1257.

[34] Lindner, J., Murphy, T., \& Briers, G. (2001). Handling Nonresponse In Social Science Research. Journal of Agricultural Education, 42(4).

[35] Lynd - Stevenson, R. M. (1999). Expectancy - value theory and predicting future employment status in the young unemployed. Journal of Occupational and Organizational Psychology, 72(1), 101-106.

[36] McCormack, A., Gore, J., \& Thomas, K. (2006). Early career teacher professional learning. Asia - Pacific Journal of Teacher Education, 34(1), 95-113.

[37] Merriam-Webster. (n.d.). Retrieved from https://www.merriam-webster.com/

[38] Monk, D. H. (1994). Subject area preparation of secondary mathematics and science teachers and student achievement. Economics of Education Review, 13(2), 125-145.

[39] Murray, K., Flowers, J., Croom, B., \& Wilson, B. (2011).
The Agricultural Teacher's Struggle for Balance between Career and Family. Journal of Agricultural Education, 52(2), 107-117.

[40] Myers, B. E., Dyer, J. E., \& Washburn, S. G. (2005). Problems facing beginning agriculture teachers. Journal of Agricultural Education, 46(3), 47.

[41] National Association of Agricultural Educators. (n.d.). Retrieved from https://www.naae.org/

[42] Nias, J. (1996). Thinking about feeling: The emotions in teaching. Cambridge Journal of Education, 26(3), 293-306.

[43] Parsons, J. E., Adler, T., \& Meece, J. L. (1984). Sex differences in achievement: A test of alternate theories. Journal of Personality and Social Psychology, 46(1), 26.

[44] Rea, L. M., \& Parker, R. A. (1992). Designing and conducting survey research in San Francisco. California: Jossey-Boss.

[45] Roberts, T. G., Harder, A., \& Brashears, M. T. (2016). American Association for Agricultural.

[46] Roness, D. (2011). Still motivated? The motivation for teaching during the second year in the profession. Teacher and Teaching Education, 27(3), 628-638.

[47] Rots, I., Aelterman, A., Vlerick, P., \& Vermeulen, K. (2007). Teacher education, graduates' teaching commitment, and entrance into the teaching profession. Teaching and Teacher Education, 23(5), 543-556.

[48] Scherer, M. (2001). Improving the Quality of the Teaching Force: A Conversation with David C. Berliner. Educational Leadership, 58(8), 6-10.

[49] Skaalvik, E. M., \& Skaalvik, S. (2008). Teacher self-efficacy: Conceptual analysis and relations with teacher burnout and perceived school context. Self-processes, Learning, and Enabling Human Potential, 223-247.

[50] Taylor, C., McNaney-Funk, C., Jardine, D., Lehman, G., \& Fok-Chan, E. (2014). Teacher rewards: Going beyond the stickers: Moving beyond extrinsic motivation - online Submission.

[51] UNESCO. (2017). Accountability in education: Meeting Our Commitments (First Edit). France: United Nations Educational, Scientific, and Cultural Organization.

[52] Walker, W. D., Garton, B. L., \& Kitchel, T. J. (2004). Job satisfaction and retention of secondary agriculture teachers. Journal of Agricultural Education, 45(2), 28-38.

[53] Watt, H. M., \& Richardson, P. W. (2008). Motivations, perceptions, and aspirations concerning teaching as a career for different types of beginning teachers. Learning and Instruction, 18(5), 408-428.

[54] Whittington, M. S., McConnell, E., \& Knobloch, N. A (2006). Teacher efficacy of novice teachers in agricultural education in Ohio at the end of the school year. Journal of Agricultural Education 47(4), 26-38.

[55] Wigfield, A., \& Eccles, J. S. (2000). Expectancy-value theory of achievement motivation. Contemporary Educational Psychology, 25(1), 68-81. 
[56] Wilhelm, K., Dewhurst-Savellis, J., \& Parker, G. (2000). Teacher stress? An analysis of why teachers leave and why they stay. Teachers and Teaching, 6(3), 291-304.

[57] Worthy, J. (2005). 'It didn't have to be so hard': the first years of teaching in an urban school. International Journal of Qualitative Studies in Education, 18(3), 379-398. 